\title{
PENGARUH LAYANAN KONSELING KELOMPOK DENGAN TEKNIK MODELLING UNTUK MENINGKATKAN PERILAKUALTRUISTIK PADA SISWA SEKOLAH MENENGAH PERTAMA
}

\author{
Fety Yulianti, Yessy Elita, Vira Afriyati \\ Prodi Bimbingan dan Konseling Fakultas Keguruan dan Ilmu Pendidikan \\ Universitas Bengkulu \\ fetyyulianti837@gmail.com,yessyelita@unib.ac.id, vira_afriyati@unib.ac.id
}

\begin{abstract}
ABSTRAK
Penelitian ini bertujuan untuk mengetahui pengaruh layanan konseling kelompok dengan teknik modelling untuk meningkatkan perilaku altruistik siswa di SMP Negeri 6 Kota Bengkulu. Metode yang digunakan dalam penelitian ini adalah metode eksperimen dengan desain penelitian one group pre-test dan post-test design. Sampel dalam penelitian ini adalah 8 orang siswa kelas VIII E yang memiliki tingkat perilaku altruistik rendah dan sedang. Teknik pengumpulan data dalam penelitian ini menggunakan angket. Hasil yang diperoleh dalam penelitian ini menunjukkan perilaku altruistik siswa meningkat setelah diberikan layanan konseling kelompok dengan teknik modelling. Hal ini terlihat dari hasil pre-test dan post-test $\mathrm{Z}=-2.521 \mathrm{p}=0,012$ maka $\mathrm{p}<0,05$, sehingga dapat disimpulkan Ho ditolak dan Ha diterima. Artinya terdapat pengaruh yang signifikan perilaku altruistik siswa sebelum dan sesudah diberikan layanan konseling kelompok dengan teknik modelling.
\end{abstract}

Kata kunci: perilaku altruistik, layanan konseling kelompok, modelling

\section{THE INFLUENCE OF GROUP COUNSELING SERVICES WITH MODELLING TECHNIQUES TO INCREASE THE STUDENTS' BEHAVIOR OF ALTRUISTIC IN JUNIOR HIGH SCHOOL}

\begin{abstract}
This study aims to determine the effectiveness of group counseling services with modelling techniques to improve altruistic behavior of students in SMP Negeri 6 Kota Bengkulu. The method used in this research was experimental method with one group pre-test and post-test design. The sample in this research is 8 students from class VIII E who have low and moderate altruistic behavior level. Data collection techniques in this study using a questionnaire. The results obtained in this study showed that students' altruistic behavior increased after group counseling service with modelling technique. It was seen from the results of pretest and post-test $\mathrm{Z}=-2.521 \mathrm{p}=0,012$ then $\mathrm{p}<0,05$, so it can be concluded Ho rejected and $\mathrm{Ha}$ accepted, and $\mathrm{Ha}$ accepted, it means there are significant influence of altruistic behavior of students before and after being given group counseling services with modelling techniques.
\end{abstract}

Keywords: altruistic behavior, group counseling services, modelling 


\section{Pendahuluan}

Manusia secara hakiki merupakan makhluk sosial, yang tidak akan sanggup hidup sendiri, selalu bergantung kepada orang lain dan apa yang dibutuhkannya dalam hidup juga dibutuhkan pula oleh orang lain. Sejak lahir manusia sudah membutuhkan orang lain untuk memenuhi kebutuhannya. Menurut Munib (2012: 14) perwujudan manusia sebagai makhluk sosial dimulai dari adanya kenyataan bahwa manusia tidak dapat memenuhi kebutuhan semasa hidupnya tanpa bantuan orang lain. Oleh sebab itu, sebagai bagian dari makhluk sosial selain menjalankan tugas akademik, peserta didik dalam kesehariannya tidak terlepas dari lingkungan sosialnya. Dengan demikian, sebagai makhluk sosial hendaknya manusia saling tolong-menolong satu sama lain dan mengadakan interaksi dengan orang lain untuk bertukar pikiran serta untuk memenuhi kebutuhan hidupnya.

Sears (dalam Nashori, 2008: 34) perilaku altruistik adalah tindakan sukarela yang dilakukan oleh sekelompok orang untuk menolong orang lain tanpa mengharapkan imbalan apapun (kecuali perasaan telah melakukan kebaikan). Altruistik juga dapat dipahami sebagai perhatian yang bersifat senang untuk mempedulikan kepentingan orang lain, lawan dari sifat egoisme.

Comte (dalam Taufik, 2012: 131) membedakan antara perilaku menolong yang altruis dengan perilaku menolong yang egois. Menurutnya dalam memberikan pertolongan, manusia memiliki dua motif (dorongan), yaitu altruis dan egois. Kedua dorongan tersebut sama-sama ditujukan untuk memberikan pertolongan. Perilaku menolong yang egois tujuannya justeru mencari manfaat untuk diri si penolong atau memanfaatkan orang yang ditolong. Sedang perilaku menolong altruis adalah semata-mata untuk kebaikan.

Myers (dalam Sarwono, 2002: 328) menyatakan bahwa altruisme sebagai hasrat untuk menolong orang lain tanpa memikirkan kepentingan sendiri. Altruisme dapat ditunjukkan individu karena pada dasarnya manusia adalah makhluk yang suka menolong (altruis). Orang yang mementingkan kepentingan orang lain daripada kepentingan dirinya disebut altruis. Pandangan tentang mementingkan orang lain disebut altruisme. Sedangkan sifat mengutamakan kepentingan orang lain disebut altruistis/altruistik. 
Salah satu tugas guru bimbingan dan konseling yang berada disekolah adalah mengarahkan dan membimbing perilaku siswa agar berkembang secara optimal sesuai dengan fungsi dan tujuan pendidikan melalui layanan bimbingan dan konseling. Hasil observasi menunjukkan bahwa, beberapa siswa menunjukkan sikap tidak peduli dengan keadaan orang lain. Siswa hanya mementingkan kepentingannya sendiri, tidak empati terhadap penderitaan yang dialami oleh temannya. Selain itu juga terdapat siswa yang tidak bersedia memberikan penjelasan mengenai pelajaran ketika temannya mengalami kesulitan. Seharusnya siswa dapat menjalin ikatan kebersamaan, baik di dalam maupun di luar kelas, serta saling tolong-menolong terhadap teman atau orang lain yang ada di lingkungannya. Adanya persoalan tersebut sehingga penelitian ini dilakukan. Layanan bimbingan dan konseling yang diberikan dapat membantu siswa dalam mengentaskan permasalahan yang dihadapinya dan mencegah terjadinya masalah yang lain.Salah satu layanan yang dapat diberikan untuk meningkatkan perilaku altruistik siswa adalah menggunakan layanan konseling kelompok dengan teknik modelling.

Prayitno \& Amti, (2004: 311), layanan konseling kelompok pada dasarnya adalah layanan konseling perorangan yang dilaksanakan di dalam suasana kelompok. Disana ada konselor dan ada klien, yaitu para anggota kelompok. Disana terjadi hubungan konseling dalam suasana yang diusahakan sama seperti dalam konseling perorangan yaitu hangat, terbuka dan penuh keakraban. Menurut Gazda (dalam Adhiputra, 2015: 24) konseling kelompok merupakan suatu sistem layanan bantuan yang baik untuk membantu pengembangan kemampuan pribadi, pencegahan, dan menangani konflik-konflik antar-pribadi atau pemecahan masalah.

Teknik yang digunakan adalah menggunakan teknik modelling. Menurut Erford (2016: 340), modelling adalah proses bagaimana individu belajar dari mengamati orang lain.Menurut Bandura (dalam Dayakinsin dan Hudaniah, 2015: 13), modelling adalah salah proses bagaimana individu belajar dari mengamati orang lain. Anak belajar tingkah laku baru dengan melihat orang lain yang melakukannya dan mengamati akibat dari sejumlah tingkah laku. Jika model yang 
melakukannya mendapat reward (ganjaran), maka tingkah laku itu akan dilakukannya pada yang akan datang. Tetapi jika model tersebut medapatkan punishment (hukuman), pengamat akan kurang suka melakukan tingkah laku tersebut.

Penerapan layanan konseling kelompok dengan teknik modelling efektif untuk meningkatkan perilaku altruistik siswa. Menurut Bandura (dalam Corey, 2010: 222) dengan teknik modelling individu dapat meniru perilaku model yang diamatinya dan memperkuat perilaku yang sudah terbentuk tanpa rasa takut mengalami akibat-akibat yang menakutkan dengan tindakan yang dialaminya. Tujuan dalam penelitian ini adalah untuk melihat pengaruh dari layanan konseling kelompok dengan teknik modelling terhadap peningkatan perilaku altruistik siswa.

\section{Metode Penelitian}

Dalam penelitian ini, metode yang digunakan adalah metode eksperimen. Desain penelitian yang digunakan adalah pre-experimental design dengan jenis desain one group pre-test and post test. Pre-test dilakukan untuk mengukur perilaku altruistik siswa sebelum diberikan perlakuan konseling kelompok dengan teknik modelling dan post-test dilakukan untuk mengukur perilaku altruistik siswa setelah diberikan layanan konseling kelompok dengan teknik modelling. Sebelum dilakukan pre-test, terlebih dahulu dilakukan uji coba instrumen kepada kelas tetangga untuk di uji validitas, reliabilitas dan daya beda aitem. Uji coba instrumen dilakukan untuk mengetahui apakah instrumen yang digunakan telah valid dan reliabel.

Sampel adalah bagian dari populasi yang memiliki ciri-ciri atau keadaan tertentu yang akan diteliti (Martono, 2014: 76). Teknik pada penelitian sampel ini, menggunakan teknik purposive sampling yaitu teknik penentuan sampel dengan pertimbangan tertentu (Sugiyono, 2008:124). Sampel dalam penelitian ini adalah 8 orang siswa kelas VIII E yang memiliki perilaku altruistik rendah.

Teknik pengumpulan data yang digunakan adalah menggunakan skala dengan model skala Likert. Skala Likert digunakan untuk mengukur sikap, pendapat dan persepsi seseorang atau sekelompok orang tentang fenomena sosial 
(Sugiyono, 2008: 134). Angket disusun dengan menggunakan 5 alternatif pilihan jawaban yaitu : sangat setuju (SS), setuju (S), ragu-ragu (RR), tidak setuju (TS), dan sangat tidak setuju (STS).Angket tersebut berisi pernyataan tentang perilaku altruistik yang merujuk pada ciri-ciri perilaku altruistik menurut Choen yaitu : empati, keinginan memberi dan sukarela.

Skala atau alat ukur yang digunakan telah memenuhi uji validitas, uji reliabilitas. Jenis validitas yang digunakan adalah validitas isi. Validitas isi (content validity) adalah cara mengukur sejauh mana alat isi pengukur yang mewakili seluruh aspek yang dianggap sebagai kerangka konsep yang akan diukur. Validitas isi dapat dicapai dengan menyusun indikator konsep dari variabel yang cukup luas, sehingga benar-benar dapat mengukur variabel yang dioperasikan (Martono, 2014:100). Uji validitas ini dilakukan dengan 3 orang ahli. Pada uji reliabilitas menggunakan standar Alpha Cronbach sebesar 0,6930. Hasil uji reliabilitas dari 56 item diperoleh Alpha Cronbach sebesar 0,878. Syarat uji daya beda yang digunakan adalah 0,30, dari 56 aitem 32 aitem dinyatakan valid dan 24 dinyatakan gugur. Alpha Cronbach dari 32 aitem tersebut adalah 0,899. Uji hipotesis dilakukan dengan menggunakan bantuan program komputer paket Statistical Packages for Sosial Science (SPSS) for Window Release 21 dengan menggunakan rumus wilcoxon. Wilcoxon digunakan untuk menganalisis hasil-hasil pengamatan yang berpasangan dari dua data apakag berbeda atau tidak. Tes wilcoxon dicari dengan cara mencari perbedaan antara skor pre-test dan post test dengan.

\section{Hasil dan Pembahasan}

Adapun peningkatan skor dari hasil pre-test danpost-test peningkatan perilaku altruistik pada siswa kelas VIII E dapat dilihat pada Tabel 1. 
Tabel 1

Peningkatan Skor

\begin{tabular}{ccccccc}
\hline NO & Responden & $\begin{array}{c}\text { Skor } \\
\text { Pre-test }\end{array}$ & Kategori & $\begin{array}{c}\text { Skor } \\
\text { Post-test }\end{array}$ & Kategori & $\begin{array}{c}\text { Skor } \\
\text { Peningkatan }\end{array}$ \\
\hline 1 & JL & 98 & Sedang & 143 & Tinggi & 45 \\
\hline 2 & MF & 98 & Sedang & 142 & Tinggi & 44 \\
\hline 3 & SP & 87 & Sedang & 138 & Tinggi & 51 \\
\hline 4 & HR & 104 & Sedang & 142 & Tinggi & 38 \\
\hline 5 & DA & 74 & Rendah & 148 & Tinggi & 74 \\
\hline 6 & RA & 71 & Rendah & 141 & Tinggi & 70 \\
\hline 7 & DR & 99 & Sedang & 142 & Tinggi & 44 \\
\hline 8 & FP & 112 & Sedang & 151 & Tinggi & 39 \\
\hline & Mean & 92,8 & Sedang & 143,3 & Tinggi & \\
\hline & Jumlah & 743 & & 1.147 & & 404 \\
\hline
\end{tabular}

Hasil analisis dari Tabel 1 dapat diketahui bahwa pada saat pre-test dari 8 orang siswa 2 orang termasuk dalam kategori rendah dan 6 orang lainnya termasuk ke dalam kategori sedang. Nilai skor rata-rata siswa pada saat pre-test adalah 92,8. Setelah dilakukan pemberian treatmentberupa layanan konseling kelompok dengan teknik modelling, kemudian siswa diberikan angket untuk dilakukan post-test. Hasil post-test menunjukkan bahwa 8 orang siswa tersebut masuk dalam kategori tinggi, dengan skor rata-rata meningkat menjadi 143,3. Hal ini menunjukkan bahwa terdapat peningkatan perilaku altruistik siswa.

Sebelum dilakukan uji hipotesis, dilakukan uji normalitas data terlebih dahulu. Uji normalitas data pre-test dan post-test dapat dilihat pada Tabel 2. 
Tabel 2

\section{Uji Normalitas Data}

\begin{tabular}{cc}
\hline & Sig. \\
\hline Pre-test & $0,632(\mathrm{p}>0,05)$ \\
\hline Post-test & $0,529(\mathrm{p}>0,05)$ \\
\hline
\end{tabular}

Berdasarkan Tabel 2 dapat diketahui bahwa nilai signifikan variabel perilaku altruistik sebelum diberikan perlakuan (pre-test) yaitu 0,632 ( $\mathrm{p}>0,05)$ dan setelah diberikan perlakuan (post-test) yaitu 0,529 ( $\mathrm{p}>0,05)$, sehingga dapat disimpulkan bahwa data berdistribusi normal.

Hipotesis dalam penelitian ini adalah untuk menguji apakah terdapat pengaruh layanan konseling kelompok dengan teknik modelling untuk meningkatkan perilaku altruistik siswa kelas VIII E di SMP Negeri 6 Kota Bengkulu, maka untuk menguji hipotesis tersebut peneliti menggunakan uji-z dengan menggunakan SPSS versi 21 dengan uji Wilcoxon Signed Ranks Test. Hasil yang diperoleh dapat dilihat pada Tabel 3.

Tabel 3 Hasil Penelitian

Wilcoxon Signed Rank Test (Uji Z)

\begin{tabular}{lc}
\hline & Pre test -Post test \\
\hline $\mathrm{Z}$ & -2.521 \\
Asym. Sig (2-tailed) &, 012 \\
\hline
\end{tabular}

BerdasarkanTabel 3 dapat diketahui bahwa, ketika penerimaan atau penolakan hipotesis adalah jika nilai signifikansi (2-tailed) $<0,05$ maka Ho ditolak, namun jika nilai signifikansi (2-tailed) > 0,05 maka Ho diterima. Hasil perhitungan Tabel 3 diperoleh nilai signifikan sebesar 0,012 yang berarti $\mathrm{P}<0,05$ maka Ho ditolak Ha diterima. Maka dapat disimpulkan bahwa, terdapat pengaruh layanan konseling kelompok dengan teknik modelling untuk meningkatkan perilaku altruistik pada siswa kelas VIII E di SMPN 6 Kota Bengkulu. 
Sesuai dengan tujuan penelitian, yaitu untuk meningkatkan perilaku altruistik dengan menggunakan layanan konseling kelompok dengan teknik modelling pada siswa kelas VIII E di SMP Negari 6 Kota Bengkulu, maka dari penjelasan diatas maka terbukti bahwa konseling kelompok dengan teknik modelling efektif untuk meningkatkan perilaku altruistik.

Menurut Taylor (2009: 457), altruisme adalah tindakan sukarela yang dilakukan individu atau sekelompok individu untuk menolong orang lain tanpa mengharapkan imbalan apapun. Suatu perilaku dikatakan altruistik tergantung pada tujuan si penolong. Keterikatan antar-individu diharapkan dapat menumbuhkan kesediaan untuk memberikan bantuan kepada orang lain kapanpun dan tanpa mengharapkan timbal balik dari orang maupun keluarga yang ditolongnya.Setiap individu harus memiliki perilaku altruisme karena menurut Batson (dalam Myers 2012: 208), keuntungan altruisme yang didorong berdasarkan motivasi empati yaitu : memunculkan perilaku menolong yang sensitif, ketika terdapat empati bukan hanya pikiran yang diperhitungkan melainkan keinginan untuk meringankan penderitaan orang lain, mencegah agresi, orang yang altruistik cenderung pemaaf dan tidak suka dengan kekerasan, meningkatkan kerja sama, karena orang yang altruistik akan berkolaborasi untuk meminimalkan musibah yang dialami orang lain, dan meningkatkan sikap terhadap kelompok-kelompok yang mendapat stigma tertentu, mengambil sudut pandang orang lain, membiarkan diri anda merasakan apa yang mereka rasakan.

Layanan konseling kelompok merupakan salah satu layanan yang dapat digunakan untuk meningkatan perilaku altruistik siswa. Menurut Asmani (2010:116), layanan konseling kelompok adalah layanan bimbingan dan konseling yang memungkinkan peserta didik memperoleh kesempatan untuk membahas dan mengentaskan permasalahan yang dialaminya melalui dinamika kelompok. Masalah yang dibahas adalah masalah-masalah pribadi yang dialami oleh masingmasing anggota kelompok. Tujuan konseling kelompok menurut Prayitno (dalam Tohirin, 2007: 181), secara umum tujuan layanan konseling kelompok adalah berkembangnya kemampuan sosialisasi siswa, khususnya kemampuan 
berkomunikasinya. Melalui layanan konseling kelompok, hal-hal dapat menghambat atau mengganggu sosialisasi dan komunikasi siswa diungkap dan didinamikakan melalui berbagai teknik, sehingga kemampuan berkomunikasi dan bersosialisasi siswa berkembang optimal. Melalui layanan konseling kelompok juga dapat dientaskan masalah siswa dengan memanfaatkan dinamika kelompok. Secara khusus para anggota kelompok memperoleh dua tujuan sekaligus yaitu :

a. Berkembangnya perasaan, pikiran, persepsi, wawasan dan sikap terarah kepada tingkah laku khususnya bersosialisasi dan berkomunikasi. b. Terpecahnya masalah individu yang bersangkutan dan diperolehnya pemecahan masalah tersebut bagi individu-individu lain yang menjadi peserta layanan.

Penggunaan teknik modelling sebagai strategi pemecahan masalah yang dialami oleh siswa dalam meningkatkan perilaku altruistik siswa.Menurut Bandura (dalam Dayakinsin dan Hudaniah, 2015: 13), modelling adalah salah proses bagaimana individu belajar dari mengamati orang lain.Menurut Bandura (dalam Susati, 2013), strategi modelling merupakan strategi dalam konseling yang menggunakan proses belajar melalui pengamatan terhadap model dan perubahan perilaku yang terjadi karena peniruan.Teknik modelling yang dipilih yaitu berupa pemberian video mengenai perilaku altruistik.

Judul video yang ditampilkan pada pertemuan pertama konseling kelompok yaitu berjudul "Ikhlas dari hati". Pada pertemuan kedua konseling videoyang ditampilkan yaitu berjudul "Bermimpi dari sesuatu yang ditakuti" Konseling ketiga menampilkan video yang berjudul "Tolong menolong harus ikhlas". Pada konseling keempat video yang ditampilkan berjudul "Jangan berburuk sangka". Kemudian pada konseling kelima menampilkan video yang berjudul "Bapak Usman berhati mulia". Konseling yang terakhir yaitu berjudul "Kebaikan yang kita tabur akan kembali padamu". Berdasarkan video-videoyang sudah ditonton tersebut, siswa tidak hanya mengerti teorinya saja melainkan mereka juga mampu mengamati serta memahami apa yang diinginkan oleh konselor dan terjadi perubahan perilaku karena adanya peniruan (modelling). Teknik modelling adalah suatu teknik untuk membantu konseli belajar mengubah perilakunya melalui suatu contoh dan pengamatan terhadap model yang ditampilkan. 
Setelah diberikan layanan konseling kelompok dengan teknik modelling, terjadi peningkatan perilaku altruistik siswa. Hal ini terlihat dari hasil post-test yang telah diberikan, dari delapan orang anggota kelompok yang sebelumnya tergolong dalam kategori 2 orang rendah dan 6 orang berada pada kategori sedang setelah diberikan layanan konseling kelompok dengan teknik modelling meningkat menjadi tinggi.

Pada awal pertemuan siswa lebih banyak diam hanya sebagai pendengar tidak mau berbicara jika belum ditunjuk. Peneliti berusaha membangun kelompok dengan menanggapi salah satu masalah yang dialami anggota kelompok untuk dibahas dan meminta anggota kelompok untuk memberikan contoh solusi yang sekiranya dapat dilakukan dan menyelesaikan masalah tersebut. Peneliti juga menunjuk para anggota kelompok untuk menolong temannya agar mereka mau untuk membantu temannya yang mengalami masalah dengan memberikan solusi terbaik mereka. Peneliti juga mengajak para siswa untuk melakukan senam otak agar suasana dalam kelompok menjadi lebih akrab dan tidak membosankan. Pemberian treatmentdilakukan sebanyak 6 kali pertemuan. Setelah mendapatkan layanan konseling kelompok, siswa terlihat menjadi lebih peka terhadap anggota kelompok yang lain dengan memberikan tanggapan yang positif terhadap temannya yang masalahnya dibahas, memberikan semangat, dan menunjukkan rasa kepeduliannya

Selama enam kali pemberian treatmentyang telah dilakukan yaitu berupa layanan konseling kelompok dengan teknik modelling, anggota kelompok semakin akrab dan makin terbuka untuk berbagi cerita, pengalaman dan informasi. Sehingga setiap pertemuan terjadi peningkatan. Dengan dinamika kelompok ini, individu menjadi terbuka pada diri sendiri dan terbuka pada orang lain. Dari berbagai uraian tersebut dapat disimpulkan bahwa ada perbedaan perilaku altruistik siswa sebelum dan sesudah diberikan layanan konseling kelompok dengan teknik modelling pada siswa kelas VIII E di SMP Negeri 6 Kota Bengkulu. Hal ini menunjukkan bahwa layanan konseling kelompok efektif untuk untuk meningkatkan perilaku altruistik siswa. 


\section{Kesimpulan}

Hasil pre-test 8 orang siswa sebelum mendapatkan treatment memiliki ratarata skor sebesar 92,8. Sedangkan setelah dilakukan 6 kali pemberian treatment rata-rata skor meningkat menjadi 143,3. Berdasarkan hasil analisis data dapat disimpulkan bahwa layanan konseling kelompok dengan teknik modelling berpengaruh terhadap peningkatan perilaku altrusitik siswa kelas VIII E di SMP Negeri 6 Kota Bengkulu.

Diharapkan kedepannya siswa dapat menunjukkan perilaku altruistik yang tinggi dalam kehidupan sehari-hari. Sebagai seorang guru BK perlu untuk memberikan layanan bimbingan dan konseling khususnya layanan konseling kelompok secara rutin sehingga siswa dapat berperan aktif didalamnya. Selain menyelesaikan permasalahannya siswa juga dapat membantu anggota kelompok lain untuk menyelesaikan masalahnya. Bagi peneliti selanjutnya diharapkan dapat melakukan kegiatan konseling kelompok dengan teknik yang berbeda dengan menggunakan media yang tepat untuk mendukung keberhasilan layanan konseling kelompok.

\section{Daftar Pustaka}

Adhiputra, N. (2015). Konseling Kelompok. Yogyakarta: Media Akademi.

Asmani, J.M. (2010). Bimbingan dan Konseling di Sekolah. Jogjakarta: Diva Press.

Azwar, S. (1999). Penyusunan Skala Psikologi. Yogyakarta: Pustaka Pelajar.

Erford, B.T. (2015). 40 Teknik yang Harus Diketahui Setiap Konselor.Jakarta:Pustaka Belajar.

Corey, G. (2010). Teori dan Praktek Konseling \& Psikoterapi.Bandung: Refika Aditama.

Dayakinsin, T,. dan Hudaniah. (2015). Psikologi Sosial. Malang: UMM Press.

Myers, D.G. (2012). Psikologi Sosial Jilid 2. Jakarta. Salemba Humanika.

Martono, N. (2014). Metode Penelitian Kuantitatif. Jakarta: Raja Grafindo Persada.

Munib, A. (2012). Pengantar Ilmu Pendidikan. Semarang: UPT UNNES Press. 
Nashori, F. (2008). Psikologi Sosial Islam. Bandung: Refika Aditama.

Prayitno,danAmti, E. (2004). Dasar-dasar Bimbingan dan Konseling.Jakarta: Rineka Cipta.

Sarwono, S. W. ( 2002). Psikologi Sosial. Jakarta: Balai Pustaka.

Sugiyono .(2008). Metode Penelitian Pendidikan Pendekatan Kuantitatif, Kualitatif,dan $R \& D$. Bandung: Alfabeta.

Susati, A.R. (2013). Penerapan Konseling Kelompok dengan Strategi Modeling Simbolis untuk Meningkatkan Keaktifan Siswa. Jurnal BK Universitas Negeri Semarang, 04(1), 437-444.

Taufik. (2012). Empati Pendekatan Psikologi Sosial. Jakarta: Raja Grafindo Persada.

Taylor, A.E., Sears, D.O. \& Peplau, L.A. (2009). Psikologi Sosial Edisi Kedua Belas. Jakarta: Kencana. 